\title{
The process of forming the synergetic effect in the industrial cluster and its economic evaluation
}

\author{
L.A. Suvorova ${ }^{1, *}, T . V$. Baibakova $^{1}$, and I.V. Pestova ${ }^{1}$ \\ ${ }^{1}$ Economics department, Vyatka State University, Kirov, Russia
}

\begin{abstract}
The synergetic effect of an industrial cluster is considered by the authors as a quasi-effect that has a complex non-linear nature and consists of a number of diverse effects. The authors of the article investigate the formation of synergetic effect in the industrial cluster, as well as the indicators of its economic evaluation. In contrast to the proposed approaches to describing the process of forming the synergetic effect in the industrial cluster, which are based on determining the effects of various kinds (economic, social, environmental, tax, etc.), the authors propose the approach based on the concept "value added". For its economic assessment the researchers consider the following indicator: a synergetic effect of multiplicative-accelerative clustering (SeMAC). The results of the synergetic effect evaluation of the leading clusters of the Russian Federation in the direction of "Biopharmaceuticals, biotechnology and biomedicine" allow us to conclude that the developed scheme of forming the synergetic effect of the industrial cluster. Also the developed indicators of its economic evaluation are common and allow to get the objective data.
\end{abstract}

\section{Introduction}

Nowadays Russia implements the Conception of the long-term social and economic development of the Russian Federation for the period up to 2020 (the Conception further).

The strategic goal of the Conception is "to achieve the level of economic and social development according to the status of Russia as the leading world power of the XXI century, which has an attractive way of life and leading positions in the global economic competition and which ensures the national security and the implementation of its citizens' constitutional rights [1]".

To achieve this goal Russia needs to undergo the transition of the economy to the innovative type of development. This is possible if we can form new centers of economic growth. These centers allow to combine the scientific, educational and industrial potential and ensure the rising competitiveness of enterprises, research organizations and educational institutions that have a positive effect on economic development, encourage investment and create new jobs. These centers are innovative industrial clusters [2].

Cluster policy as the basis for development of the country is an alternative to traditional industrial policy. This is because the cluster policy aims at creating and distributing innovative products that are considered to be the basic tools for increasing the competitiveness of enterprises, regions and the whole country. Besides, in the process of clustering branches the synergetic effect appears, and it allows to increase the efficiency of using branches through resource interchange.
The synergetic effect as a quasi-effect increases the speed of circulation of information, and therefore it acts as a catalyst in the development of production, sales, financial, scientific and technical spheres of society.

One of the obstacles for clustering the Russian industrial sector is the lack of examining of theoretical and practical aspects connected with the understanding of the formation of the synergetic effect and its economic evaluation.

\section{Defining the task of the research}

Today there are a lot of publications concerning this problem [3-16].

Despite this fact, there are no studies that examine the process of forming synergetic effect of the industrial cluster in terms of the formation of value added by combining the cost optimization and accelerating the pace of the industrial cluster development. In addition, there are no studies that assess the synergetic effect in terms of multiplicative-accelerative approach.

\section{The developing of the process of forming the synergetic effect of the indastrial cluster}

The synergistic effect of the industrial cluster has a complex non-linear nature, consisting of a number of mechanisms for forming different effects.

Pechatkin V., Perfilov V. [18] distinguish four types of effects, forming the synergetic effect. They are: economic 
effect, social effect, budgetary effect and ecological effect (Table I).

Table1. The Description of the Clustering Effects that Make the Synergetic effect.

\begin{tabular}{|l|l|}
\hline \multicolumn{1}{|c|}{ Effect } & \multicolumn{1}{c|}{ The Result of the effect } \\
\hline $\begin{array}{l}\text { Economic } \\
\text { effect }\end{array}$ & $\begin{array}{l}\text { The increase in the gross regional product } \\
\text { The increase in investment in fixed capital. } \\
\text { The increase in the innovative products output. }\end{array}$ \\
\hline Social effect & $\begin{array}{l}\text { Creating new jobs and reducing the unemployment } \\
\text { level. } \\
\text { The increase in real wages of workers engaged in the } \\
\text { cluster. }\end{array}$ \\
\hline $\begin{array}{l}\text { Budgetary } \\
\text { effect }\end{array}$ & $\begin{array}{l}\text { The growth of the tax revenue coming to budgets of } \\
\text { different levels. } \\
\text { Increasing the rate of autonomy of the regional } \\
\text { economy. }\end{array}$ \\
\hline $\begin{array}{l}\text { Ecological } \\
\text { effect }\end{array}$ & $\begin{array}{l}\text { Increased investment in environmental protection, } \\
\text { increased trapping of pollutants from the atmosphere, } \\
\text { reducing the emissions of pollutants into the } \\
\text { atmosphere. }\end{array}$ \\
\hline
\end{tabular}

Skiba A. [19] defines the following forces forming the synergetic effect of the industrial cluster: strengthening the coherence and the organizational and functional interaction between the elements of the system; the synchrony of the cycles, which characterize the operation of these elements; the consistency of the parameters of external control pulses with the parameters of the internal cycle system.

Patrusheva E. [20] states that: "Provided the non-linearity of the synergetic effect, we can say that the synergetic effect can be obtained as a result of the effect of the partnership, the effect of the flexibility of management decisions... Under the effect of the partnership we mean the economic effect that is manifested in inclusion of individual organizations in one cluster and when the organizations get the advantages of highquality development of their economic activities on this basis. This effect is reflected while assessing the net current value of the investment project. While assessing one should take into account the expected cash income from the product production, cost optimization in cooperation with the project partners, training, finding new sales markets, etc."

According to the authors, the process of forming the synergetic effect of the industrial cluster is associated with the process of the accelerated formation of value added as a result of realizing the innovative projects of the industrial cluster.

The process of forming value added in the industrial cluster is shown as the scheme on Figure 1.

The formation of value added is realized through combining the costs of optimization and accelerating the growth rate of the cluster.

If we consider the beginning of forming the additional costs as the basis of the synergetic effect, the center is an innovation. Realizing through the industrial cluster potential an innovation turns into a social product, which has the total value-added.

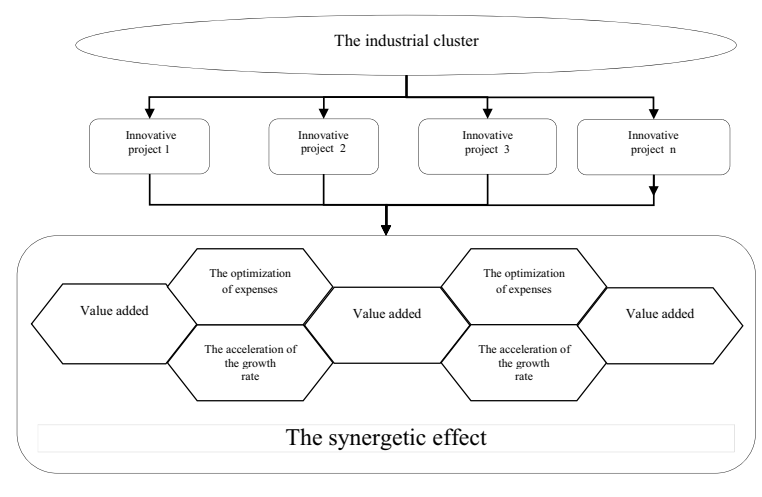

Fig. 1. The process of forming value added in the indastrial cluster.

As a result, the process of forming the synergetic effect of the industrial cluster can be represented in the form of Pascal's triangle (Figure 2).

Figure 2 shows that in order to transform one conventional unit of the innovation (I) into a conventional product (P) you need one conventional unit of financial sources (FS) and jobs (J). Further, financial sources and the product create a new product $(\mathrm{P})$, which in turn provides new sources of finance (FS), and the combination of the product (P) and jobs (J) provides its financial sources (FS) and by implication new jobs (J) and so on. As a result, one conventional unit of the innovation yielded 8 conventional units of financial sources, 6 conventional units of the product and 4 conventional units of jobs.

The presented process can be correlated with the multiplicative and accelerative mechanism [21-23]. In the economy this mechanism acts through the multiplier (income increment) and the accelerator (investment increment), which interact with each other and form resonance. The final result of the accumulated resonance is different effects that all together form the synergetic effect.

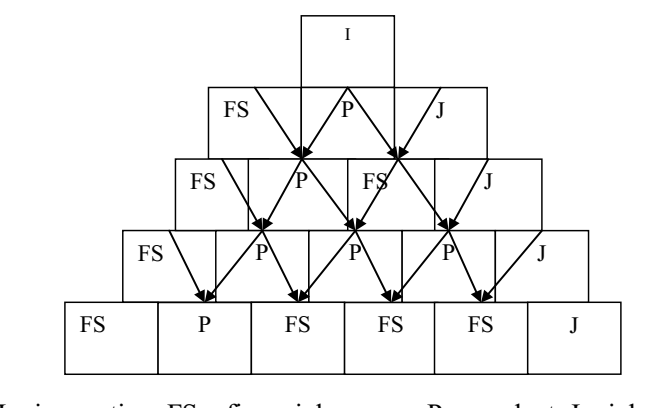

Fig. 2. Forming the Synergetic Effect of the Indastrial Cluster on the Model of Pascal's Triangle.

Thus, obtaining the synergetic effect in the industrial cluster primarily depends on the innovation, potential of the initial dimension of the cluster, as well as on the direction of this potential development. In addition, the synergetic effect of the industrial cluster also depends on the combination of multiplicative and accelerative influence of the innovation. 


\section{Developing the Indicators of Economic Evaluation of the Synergetic Effect of the Indactrial Cluster}

The purpose of the economic evaluation of the synergetic effect is to determine the aggregate economic and social benefits received from the operation of the quasi-integrated structure. The defined purpose forms a number of tasks [24]:

1) To evaluate the level of the synergetic effect as a whole.

2) To evaluate the level of the synergetic effect components.

3) To evaluate the impact of the components on the value of the synergetic effect.

The object of the economic evaluation of the synergetic effect is the industrial cluster formed by different kinds and types of organizations $[25,26]$.

The subject of the economic evaluation of the synergetic effect of the industrial cluster activities is the following: the activities and functions of the organizations within the industrial cluster; property that belongs to the organizations within the cluster; separate management problems of the cluster.

The evaluation of the synergetic effect of the industrial cluster should be based on two structural groups of principles:

1) The group of methodological principles, i.e. the group of general principles relating to the concept of synergy in the industry clustering.

2) The group of methodic principles, i.e. principles that are directly related to the operation of a particular cluster, its specific nature, its economic and financial attractiveness.

The represented groups of principles for evaluating the synergetic effect of the industrial cluster define a number of effects belonging to the synergetic effect of the cluster [26]. Nowadays modern scientists identify eight indicators: the economy of scale, the effect of the accelerator, the practical effect, the investment effect, the multiplier effect, the budgetary effect, the level of clustering and the synergetic effect (Table II).

Table 2. Modern Indicators of Calculating the Synergetic Effect.

\begin{tabular}{|l|l|}
\hline The effect name & \multicolumn{1}{c|}{ Indicators } \\
\hline Economy of scale & $\begin{array}{l}\text { The consolidated revenues of the enterprises } \\
\text { interacting in the industry, in billion rubles }\end{array}$ \\
\hline $\begin{array}{l}\text { The effect of the } \\
\text { accelerator }\end{array}$ & $\begin{array}{l}\text { The share of expenditures for producing innovative } \\
\text { products, in percent }\end{array}$ \\
\hline $\begin{array}{l}\text { The practical } \\
\text { effect }\end{array}$ & $\begin{array}{l}\text { The level of the cost reduction, which is realized } \\
\text { through optimizing them, in billion rubles }\end{array}$ \\
\hline $\begin{array}{l}\text { The investment } \\
\text { effect }\end{array}$ & $\begin{array}{l}\text { The volume of investments in the production of } \\
\text { innovative products, in billion rubles }\end{array}$ \\
\hline $\begin{array}{l}\text { The multiplier } \\
\text { effect }\end{array}$ & $\begin{array}{l}\text { The speed of receiving the consolidated revenues of } \\
\text { enterprises cooperating in the industry, in the number } \\
\text { of turns per year }\end{array}$ \\
\hline $\begin{array}{l}\text { The budgetary } \\
\text { effect }\end{array}$ & $\begin{array}{l}\text { The amount of taxes received from producing and } \\
\text { selling investment products, in billion rubles }\end{array}$ \\
\hline $\begin{array}{l}\text { The level of } \\
\text { clustering }\end{array}$ & $\begin{array}{l}\text { The rate of revenue growth received from selling } \\
\text { innovative products, the coefficient }\end{array}$ \\
\hline $\begin{array}{l}\text { The synergetic } \\
\text { effect }\end{array}$ & $\begin{array}{l}\text { The integral effect obtained as a result of industry } \\
\text { clustering }\end{array}$ \\
\hline
\end{tabular}

According to the authors, some of the indicators proposed by scientists can be correlated with each other. For example, the economy of scale is related to the multiplier effect, the former shows the absolute value, and the latter shows the relative amount, but both indicators display the growth of the output aggregate. The investment effect is related to the effect of the accelerator, the first indicator shows the absolute value of the investment growth, and the second indicator displays the relative amount of the investment growth. In addition, the first consequence of the effects of the multiplier and the accelerator is the practical effect, and the second consequence is the budgetary effect.

Due to this fact, the authors of the article stress the necessity of making up a new concept. It is the synergetic effect of the multiplicative and accelerative synergy (SeMAC). This effect has a complex chain character on the basis of cause-and-effect relationship. this relationship is realized when every subsequent part of the chain generates a particular number of new parts, thereby forming private effects of the multiplicative and accelerative synergies, which together form the total effect of the multiplicative and accelerative synergy. If we consider the beginning of SeMAC effect, according to the authors, it is the innovation that is realized through the industrial cluster potential. The potential of each organization within the industrial cluster is the ratio of potential results to the resources of the element. Since the industrial cluster combines organizations of various activities, the potential of the cluster will be presented by the algebraic sum of the potentials that are created by each element of the cluster. Thus, obtaining the synergetic effect of the industrial cluster depends on the innovations and the initial value of the potential of each industrial cluster organization.

That's why, the authors of the article propose the universal indicator of the synergetic effect of the cluster. This universal indicator is the multiplicative three-factor model consisting of the synergetic effect multiplier, the synergetic effect and the clustering level - SeMAC (Table III).

Table 3. The Mathematical Explanation of the Model of the Synergetic Effect Evaluation of the Indastrial Cluster.

\begin{tabular}{|c|c|c|c|}
\hline A unit & Abbreviation & Formula & Explanation \\
\hline $\begin{array}{l}\text { The } \\
\text { synergetic } \\
\text { effect }\end{array}$ & $\mathrm{Se}$ & $\mathrm{Se}=\mathrm{MAC}$ & \multirow{4}{*}{$\begin{array}{l}\mathrm{B}_{\mathrm{c}}-\text { the cluster } \\
\text { consolidated revenues in } \\
\text { the current period; } \\
\mathrm{B}_{\mathrm{c}-1}-\text { the cluster } \\
\text { consolidated revenues in } \\
\text { the previous period; } \\
\text { периоде; } \\
\mathrm{I}_{\text {reew }}-\text { Expenses on } \\
\text { research, experimental } \\
\text { and engineering work } \\
\text { (REEW); } \\
\mathrm{I}_{\mathrm{c}}-\text { the investments of } \\
\text { the cluster in the current } \\
\text { period }\end{array}$} \\
\hline $\begin{array}{l}\text { The } \\
\text { synergetic } \\
\text { effect } \\
\text { multiplier }\end{array}$ & $\mathrm{M}$ & $\mathrm{M}=\mathrm{B}_{\mathrm{c}} / \mathrm{I}_{\mathrm{c}}$ & \\
\hline $\begin{array}{l}\text { The } \\
\text { synergetic } \\
\text { effect } \\
\text { accelerator }\end{array}$ & $\mathrm{A}$ & $\mathrm{A}=\mathrm{I}_{\text {reew }} / \mathrm{I}_{\mathrm{c}}$ & \\
\hline $\begin{array}{l}\text { The } \\
\text { clustering } \\
\text { level }\end{array}$ & $\mathrm{C}$ & $\mathrm{C}=\mathrm{B}_{\mathrm{c}} / \mathrm{B}_{\mathrm{c}-1}$ & \\
\hline
\end{tabular}

In order to test the proposed indicators, the authors have evaluated the synergetic effect of Russia's leading clusters in such spheres as "Biopharmaceuticals, biotechnology and biomedicine" (Table IV). 
Table 4. Evaluating the Synergetic Effect of Russia`s Leading

Clusters in the Spheres 'Biopharmaceutical, Biotechnology and Biomedicine'.

\begin{tabular}{|l|c|c|c|c|c|c|}
\hline \multicolumn{2}{|c|}{ Indicators } & 2010 & 2011 & 2012 & 2013 & 2014 \\
\hline $\begin{array}{l}\text { The clusters earnings, in } \\
\text { mln. rubles }\end{array}$ & 49.96 & 52.21 & 59.78 & 74.42 & 100.10 \\
\hline $\begin{array}{l}\text { The clusters investments, in } \\
\text { mln. rubles }\end{array}$ & 18.25 & 19.07 & 19.93 & 20.83 & 21.76 \\
\hline $\begin{array}{l}\text { The share of expenses on } \\
\text { research, experimental and } \\
\text { engineering work (REEW), } \\
\text { in mln. rubles }\end{array}$ & 9.4 & 9.82 & 10.27 & 10.73 & 11.21 \\
\hline $\begin{array}{l}\text { The synergetic } \\
\text { effect Se }\end{array}$ & 0.52 & 1.47 & 1.77 & 2.29 & 3.19 \\
\hline $\begin{array}{l}\text { The synergetic } \\
\text { effect multiplier }\end{array}$ & $\mathrm{M}$ & 2.74 & 2.74 & 3.00 & 3.57 & 4.60 \\
\hline $\begin{array}{l}\text { The synergetic } \\
\text { effect accelerator }\end{array}$ & $\mathrm{A}$ & 0.19 & 0.52 & 0.52 & 0.52 & 0.52 \\
\hline The clustering level & $\mathrm{C}$ & 1 & 1.05 & 1.15 & 1.25 & 1.35 \\
\hline
\end{tabular}

The authors found out that if the rate of these clusters development increased by $47 \%$ in 2011 , then in 2014 it increased more than three times. In other words, the positive policy in the field of innovation and investment activities of the clusters allowed to obtain the significant synergetic effect for a short period of time.

\section{Conclusion}

Summing up, we can make a conclusion that the process of forming the synergetic effect of the industrial cluster is the complex nonlinear system consisting of the mechanisms of forming value added. The speed of this process and the direction of its realization influence the results of the industrial cluster activities, the level of the industry development and also the dynamics of our country`s economic development.

\section{References}

1. The complex program for the development of biotechnologies in the Russian Federation for the period up to 2020, approved by the Government of the Russian Federation (2012)

2. A.S. Huhrin, A.A. Primak, I.A. Semaeva, N.I. Popova, Economy of agricultural and processing enterprises, 12, 32-37 (2008)

3. E.N. Knyazeva, S.P. Kurdymov, The basis of synergy. The synergistic vision of the world (Komkniga, Moscow, 2005)

4. R.A. Schinova, L.A. Suvorova, L.L. Zaushitsyna, The Bulletin of the Ural Federal University, the section of Economics and Management, 14, 3, 457-474 (2015). DOI: 10.15826/vestnik.2015.14.3.027.

5. S.V. Smirnov, G.A. Potasheva, InVestRegion, 4, 26-28 (2007)

6. G.A. Krasnov, V.V. Vinogradov, A.A. Krasnov, Economic sciences. The Bulletin of the Nizhny Novgorod
University named after N.I. Lobachevsky, 4, 219-222 (2009)

7. V.A. Bellavin, S.P. Kurdymov, E.N. Knyazeva, The regimes with difficulties and laws of co-evolution of complex systems. http://spkurdyumov.ru/evolutionism/zakony-koevolyuciislozhnyx-sistem/.

8. E.G. Lysenko, K.V. Kopach, A.S. Huhrin, The sustainable development of a private subsidiary farm: the conceptual foundations of strategic management (Moscow, Rosselhozakademia, 2006)

9. L.L. Zaushitsyna, L.A. Suvorova, Scientific Review, 6, 255-261 (2014)

10. T.A. Khudyakova, A.V. Shmidt, Proc. of The 26th International Business Information Management Association Conference, 1612-1616 (2015)

11. T.A. Khudyakova, Proc. of the International Congress on Interdisciplinary Behavior and Social Science, 295-297 (2015)

12. T.M. Khudyakova, O.B. Grekova, V.V. Kravchenko, News of the Voronezh State University of Pedagogics, Russia, 3(268) (2015)

13. R. Matthews, Economic Strategies, 33-34, 07-08 (2005)

14. O. Solvell, G. Lindqvist, C. Ketels, The Cluster Initiative Greenbook (Ivory Tower, Stockholm, 2003)

15. M. Delgado, M. Porter, S. Stern, Journal of Economic Geography, 10, 4 (2010)

16. C. Ketels, O. Solvell, Innovation Clusters in the $10 \mathrm{New}$ Member States of the European Union (Publications Office of the European Union, Luxembourg, 2006)

17. C. Ketels, O. Memedovic, International Journal of Technological Learning, Innovation and Development, 1, 3 (2008)

18. V.V. Pechatkin, V.A. Perfilov, The Instrument for evaluating the influence of implementing cluster projects on the sustainable development of Russian regions. http://www.online-science.ru

19. A.N. Skiba, The scientific articles of the System Analysis Institue of the Russian Academy of Sciences, 61 (2011)

20. E.G. Patrusheva, The Regional Economy, Russia, 4 (2015). http://uecs.ru.

21. S.U. Ermakova, The theory of the multiplier and multiplier effects in the economy (Ph.D. Dissertation, Ulan-Ude, Russia, 2006)

22. T.G. Kalyugina, V.N. Parahina, InVestRegion, 3 (2012)

23. V.M. Avramchikov, A.N. Antamoshkin, The Bulletin of the Siberian State Aerospace University, 2(54), 154-158 (2014)

24. L.A. Suvorova, Proc. Biokirov-2015, 99-103 (2015)

25. L.A. Suvorova, The synergetic effect of the industry clustering: the analysis, evaluation, forecast: a monograph (The Vyatka State University, Kirov, 2015)

26. I.V. Pestova, Proc. Biokirov-2015, 89-93 (2015)

27. S.U. Ermakova, Proc. State and society: philosophy, economics, culture, 94-95 (2005) 